\title{
Testing the Effects of Ballot Access Reform on Non-Major Party Electoral Fortunes: The Case of Florida's Revision 11
}

\author{
Scot Schraufnagel and Kerri Milita
}

The research tests the effects of egalitarian ballot access on the electoral fortunes of nonmajor party candidates for U.S. House seats. In 1998, Florida voters passed an amendment to the state constitution that removed all auxiliary barriers to ballot access for non-major parties. In bivariate and multiple regression testing, the reform is associated with a statistically significant increase in the number of non-major party candidates and their vote-share. The change, however, is small. Moreover, these increased contestation rates and vote support occur primarily in the first election cycle after the reform was adopted. Output from Tobit and GLS regression suggests that the best case scenario is about a 1.3 percent increase in the non-major party vote share in U.S. House races in Florida. The study concludes that states' pursuit of egalitarian ballot access laws will not likely create substantive expansion of minor-party electoral success.

\section{Introduction}

The U.S. electoral system remains firmly planted within the bounds of a two-party dominant system, and has been so long enough, that much of the American public recognizes only two "real" political parties in social surveys, Democrats and Republicans (Hershey 2007, Ch. 2). Duverger's Law, which states that single-member districts and plurality rule elections create two-party dominant political systems, is widely charged with stifling the electoral prospects of alternative political parties in the U.S. (see Riker 1982; Duverger 1954). Given the constraints of America's election format, scholars have posited that facilitating more egalitarian ballot access is likely the most meaningful source of reform for minor or third party advocates (Robeck and Dyer 1982; Ansolabehere and Gerber 1996; Dwyre and Kolodny 1997; Lowi 1999; Winger 1999; Boehlert 2000; Cobble and Siskind 2003; Stratmann 2005). Most frequently, suggestions for easier ballot access prescribe lowering the number of signatures required to gain a place on the ballot or alternatively allowing a candidate to simply pay a fee to gain access (Lewis-Beck and Squire 1995; Rosenkranz 1996; Dwyre and Kolodny 1997; Winger 1997; 1999).

Central to this debate is the question of the desirability of multi-party involvement in the American political system. Critics charge that disrupting a two-party dominant system may induce government instability and make

SCOT SCHRAUFNAGEL is an assistant professor of political science at Northern Illinois University. KERRI MILITA is a doctoral student of political science at Florida State University.

The American Review of Politics, Vol. 31, Spring, 2010: 25-39

(C)2010 The American Review of Politics 
automatic governing majorities less likely, risking decreased accountability to the public (APSA 1950, 1-3, 18-29; Ranney and Kendall 1956; Polsby and Wildavsky 1996; Rosenstone, Behr, and Lazarus 1996, 219-21; Sifry 2002). Advocates of electoral reform, however, champion minor parties as a causeway to more inclusive representation (Schattschneider 1960; Mazmanian 1978; Herrnson 1997) and as a fertile source of innovative public policy prescriptions (Hicks 1933; Lowi 1983; 1999; Schmidt 1989; Rosenstone, Behr, and Lazarus 1996, 222-24; Hirano and Snyder 2007). Moreover, it is argued, viable non-major party candidates allow for legitimate expression of public dissent (Bowler and Lanoue 1992; Peterson and Wrighton 1998; Stratmann 2005).

Putting the normative debate aside, this research attempts to discern the substantive significance of ballot access restrictions. Is the Australian Ballot (or Secret Ballot), which put ballot access in the hands of government officials, mostly Democrats and Republicans, and allowed them to restrict access for non-major party candidates partially to blame for the lack of nonmajor party electoral success (Evans 1917; Rusk 1970; Burden 2007; Tamas and Hindman 2007)? Or, can single-member districts and plurality rule (Duverger's Law), alone, explain the lack of non-major party electoral success in the U.S.? To explore this topic, the research takes advantage of an electoral rule change that occurred in Florida during 1998 that explicitly removed the major party advantage in obtaining ballot access. The change came via a constitutional amendment which received broad based support from state voters. ${ }^{1}$

\section{Ballot Access in Florida}

Beginning in 1928, the state of Florida instituted a policy of non-major party exclusion by abolishing procedures for minor party ballot access following the presidential election that year. ${ }^{2}$ Between 1928 and the constitutional revision in 1998, there were numerous legal challenges to Florida's ballot access rules, but state and federal courts regularly rejected the charge that they were discriminatory (Winger 1998b; Sommerville and Clemenson 1998). Moreover, in the 20 years leading up to Revision 11, legislation was introduced eight times in the state legislature, to ease ballot access requirements for non-major party candidates, all to no avail (Winger 1998b). Until the twilight of the 20th century, Florida "remained hostile toward candidates outside the Republican or Democratic parties" (Boehlert 2000, 1).

In 1997, restrictive ballot access laws were lamented with regularity at public hearings before the Florida Constitution Revision Committee (CRC) (O'Neil 1998). The Florida CRC is appointed by the elected leadership of the state and the state's chief justice and is charged with prescribing poten- 
tial constitutional changes every twenty years (Sommerville and Clemenson 1998). In 1997, the CRC was lobbied by a coalition of minor party interests united under the banner of Floridians for Fair Elections, which argued "that it's easier to get on the ballot in St. Petersburg, Russia as an independent than it is in St. Petersburg, Florida" (Boehlert 2000; Marquez 1998, A12).

Libertarian activists, in particular, mobilized supporters to call for change at every hearing held in twelve cities across the state during the summer of 1997. Eventually, members of the Reform, Green, Natural Law, and Socialist USA parties in addition to advocates from Common Cause, a group that presses for "better and cleaner" elections, would attend the hearings (Sommerville and Clemenson 1998; Winger 1998a; 1998b). This ideologically diverse coalition lobbied in unison for ballot access change. The proposed solution, Revision 11, was the first ever proposed amendment to receive unanimous approval by the CRC for placement before the voters (O’Neil 1998). ${ }^{3}$ The ballot measure was subsequently approved by state voters with 64 percent support (Florida Department of State 1998). ${ }^{4}$

\section{Testing the Effects of Revision 11}

In order to test the effects of removing all ballot restrictions for nonmajor parties and individuals, data are collected by U.S. House district for nine U.S. House elections in the state of Florida to include the four elections that took place prior to Revision 11 (1992-1998) and the five subsequent elections (2000-2008). The nine elections represent a total of 215 observations. ${ }^{5}$ An auxiliary analysis will consider only elections in which there is at least one non-major party candidate competing in the election. In this instance, there are 102 observations. The empirical analysis begins by illustrating the actual number of U.S. House races that were contested by nonmajor party candidates in the two time periods. This is followed by a bivariate comparison of non-major party voting pre- and post-reform. Finally, output from four multiple regression analyses are presented that control for other possible explanations for non-major party voting in Florida. Special attention will be paid to the substantive significance of any change in the vote share that is associated with the ballot access reform.

\section{Measuring Success}

The level of non-major party contestation is calculated by simply counting the number of elections that had someone other than a Democrat or a Republican receiving a vote. When testing change in the vote share, the proportion of votes received by all non-major party candidates in each Florida U.S. House district is used. Specifically, the total votes cast for all 
non-major party candidates in each congressional district are divided by the total number of district votes cast. In addition to minor party votes, this calculation includes votes for candidates who ran without a party affiliation as well as write-in candidates. ${ }^{6}$ These biennial values become the dependent variable in the regression analyses. The largest number of votes for nonmajor party candidates occurred in a 2006 election when two candidates who ran without party affiliation garnered a combined total of 31 percent of the district vote (Florida House District 12 race). These candidates, however, suffered a resounding defeat by the Republican candidate in the race. Notably, the election took place without a Democrat on the ballot, which points to an additional potential explanation for non-major party success (a major party missing from the ballot).

\section{Measuring Ballot Access}

The key explanatory variable is the ballot access reform that went into effect in Florida for the 2000 election cycle. Employing a dummy variable, elections prior to the reform are scored " 0 ," and those following the reform are coded "1." A positive association is expected between the non-major party vote share and the implementation of Revision 11 during the testing. Importantly, a substantively significant coefficient, dependent on the magnitude of the effect, may indicate the importance of ballot access restrictions to minor party success, vis-à-vis Duverger's Law.

\section{Control Variables}

First, the model incorporates the percentage of a district's population that is African American. Barry Burden and Steven Greene (2000) find that African Americans are less likely to be politically independent due to a strong contemporary allegiance to the Democratic Party. This control variable is calculated by dividing the total African American population in each Florida-U.S. House district by the total population of the district. ${ }^{7}$ The variable ranges from 3 percent to 58 percent during the time period of this study and is expected to have a negative relationship with minor-party voting.

Second, median district income is held constant. Barbara Norrander (1989), using the American states as her unit of analysis, reports that wealthier states are associated with fewer self-identified independents. In this case, the suggestion is that constituencies with higher median incomes are more likely to support Republican candidates (Hershey 2007, Ch. 7). ${ }^{8}$ Much like the previous demographic consideration, there is considerable disparity among Florida House districts. The minimum value for district median 
income is $\$ 28,626$, and the maximum value is $\$ 51,200$. A negative association with non-major party voting is expected.

Third, district party registration statistics are considered. In particular, the research controls for the percentage of a district's electorate that is not registered with either of the two major parties. Florida's Division of Elections provides values by U.S. House district for each election cycle in the analysis. Intuitively, a positive association should manifest between "NonMajor Party Registered" and non-major party success. However, it should be noted that there are important conceptual distinctions between registering with a minor party or opting to remain "Non-Affiliated," and actually voting for non-major party candidates in a general election. The latter is evidence of behavioral independence, and the former requires only attitudinal independence (see Hershey 2007).

Fourth, the models control for whether there was a third party presidential candidate on the ballot when voters were considering whether to support third party candidates for the U.S. House. Presumably, a third party presidential candidate might have "coattails" that sweep-in some support for third party candidates further down the ballot. In Florida, each presidential election year during the time period of this study had third party presidential candidates on the ballot. So, a dummy variable is created that is scored " 1 " for each case that took place in a presidential election year and scored "0" in congressional midterm elections. A positive association is anticipated.

Finally, the models will account for two additional critical considerations: whether a major party (Democrat or Republican) is missing from the ballot, and second, whether there is a non-major party candidate on the ballot. Predictably, non-major party voting will be higher when one of the major parties is missing, and must be lower when a non-major party candidate is missing. The two dummy variables are scored "1" if a major party candidate is left-off or if a non-major party candidate is missing and "0" otherwise.

\section{Model Specification}

The dummy variable for "Non-Major Party Missing," mentioned above, addresses concerns over the large number of observations on the dependent variable which have a value of " 0 " (113 of 215 observations). The " 0 's" indicate the absence of non-major party voting. These data may be construed as left-censored because the percentage of voters that would have supported a non-major party candidate, if one had appeared on the ballot, is unknown. Accounting for censoring by creating a dummy variable, as described above, is not ideal but does preserve the sample size and allows for a generalized least squares (GLS) regression. Notably, GLS accounts for 
values on the dependent variable that are arrayed both over time (in this case election cycles from 1992-2008) and across sections (in this research the 23 or 25 Florida U.S. House districts). More specifically, GLS regression provides estimates that are weighted to correct for heteroscedasticity and autocorrelation problems that are common with the type of cross-sectional longitudinal data employed here (see Beck and Katz 1995).

However, if the data are indeed censored, the dummy variable approach will underestimate the intercept and overestimate the slope, potentially producing inconsistent or biased estimates (Long 1997, 187). The reason for including the GLS regression with the "Non-Major Party Missing" dummy variable is to provide a comprehensive slate of statistical tests, which can gauge the effects of the ballot access reform. Presenting the results of multiple model runs is intended to assuage concerns that the findings are a product of modeling assumptions. To account for censoring, an alternative model specification is constructed. Specifically, the result of a Tobit regression (alternatively referred to as a censored regression model) is reported. J. Scott Long (1997) argues: "The Tobit model uses all of the information, including information about the censoring and provides consistent estimates of the parameters" (189).

In sum, two genres of regression are employed (GLS and Tobit) and the results of four model runs are presented. The coefficients from the first two models are obtained using GLS with robust standard errors. The initial model run excludes the dummy variable for "Non-Major Party Missing," and the second includes this consideration. Third is the Tobit regression that accounts for the possibility that the first models are compromised by the censored quality of the dependent variable. Last, a GLS regression is run using only the cases in which a third party, independent, or non-affiliated candidate appears on the ballot $(n=102)$. A Tobit model would not be appropriate in this instance, because the dependent variable does not take on the value of " 0 " (is not censored). The logic behind the test of this subset of cases is that if non-major party candidates have an easier time gaining ballot access (post-reform), they may have more resources to spend gaining actual votes in the general election. If this is the situation, greater non-major party vote shares should be evident, post-reform, all else being equal.

\section{Results}

Prior to analyzing the multiple regression output, the level of non-major party contestation in Florida U.S. House races in the two time periods is examined. The data are presented in Figure 1. The elections that occurred during the period prior to the implementation of Revision 11 reforms (19921998) were contested by non-major party candidates only 39 percent of the 


\section{Figure 1. Percent Non-Major Party Contestation: Florida U.S. House Districts ${ }^{\mathrm{a}}$}

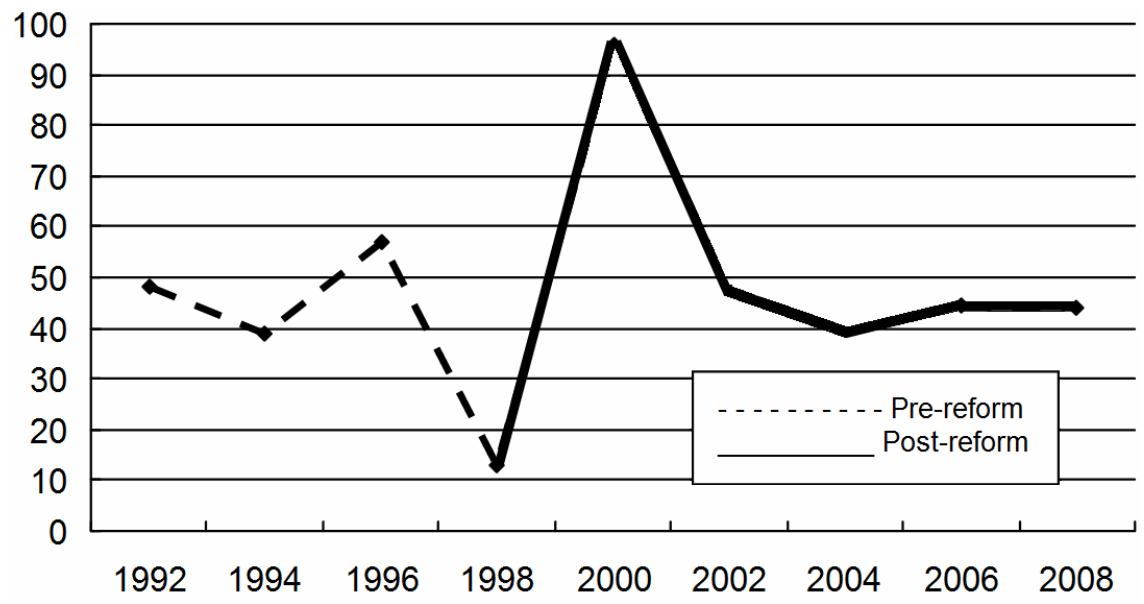

${ }^{\mathrm{a}}$ Difference of means test for two time periods $(1992-98$ and 2000-08) $t=2.12(\mathrm{p}<.05$, two-tailed test); $\mathrm{n}=215$.

Source: Florida Secretary of State-Division of Elections.

time. After the reform, the average contestation rate rises to 56 percent. The increase is statistically significant at the 95 percent confidence level.

A closer inspection of Figure 1, however, reveals that the 2000 election, the first following the passage of Revision 11, is driving the apparent boon. If this election is removed from the mix, the statistically significant increase in the level of contestation disappears $(t=-.68)$. It seems that nonmajor party candidates did initially take advantage of easier ballot access. But in succeeding elections, they retreated to pre-Revision 11 strategies and contestation levels, perhaps in light of the fact that easier ballot access did not translate into electoral victories.

Next, the research considers actual votes cast for non-major party candidates. Figure 2 exhibits the mean vote percentage garnered by nonmajor party candidates in each of the elections for the two time periods studied. The difference of means test shows the expected increase in the non-major party vote share $(t=2.06, p<.05$ two-tailed test). As with the issue of contestation, however, it seems that the election directly following the change (2000) was the most consequential. In contrast to the analysis of contestation rates, however, when the 2000 election is excluded from the analysis, a marginally significant increase in the non-major party vote share does remain $(t=1.79, p<.10$ two-tailed test $)$. The value for 2008 holds 
Figure 2. Percent Non-Major Party Vote Share: Florida U.S. House Districts ${ }^{\mathrm{a}}$

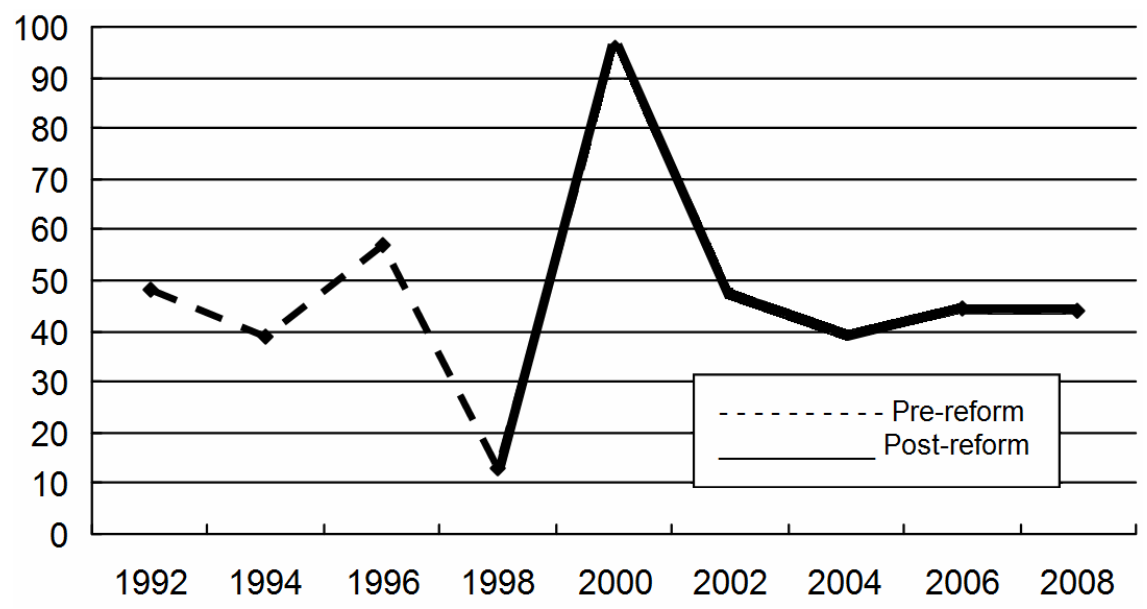

${ }^{\mathrm{a}}$ Difference of means test for two time periods (1992-98 and 2000-08) $t=2.12(\mathrm{p}<.05$, two-tailed test); $\mathrm{n}=215$.

Source: Florida Secretary of State-Division of Elections.

particular promise for non-major party advocates, representing the highest total since $2000 .^{9}$

Table 1 presents the results of the regression analyses. Both GLS and Tobit coefficients are interpreted in a manner similar to the more common ordinary least squares coefficients. Column one represents a model which includes all observations, but there is no provision for the significant number of cases where the dependent variable has the value " 0 ." The results from this model suggest the implementation of Revision 11 improved the electoral fortunes of non-major parties. But, there are limits to this increased success. First, the ballot access variable is only statistically significant using a liberal indicator of significance $(p<.10)$. Second, the value of its coefficient suggests only modest substantive gains in the non-major party vote share (about $1.2 \%)$. The model presented in column two includes the "Non-Major Party Missing" variable, and the highly significant $\mathrm{Chi}^{2}$ value indicates a better overall model fit. However, the ballot access reform loses its statistical (and consequently substantive) significance.

The third column presents the results of the Tobit model. This test suggests about a 1.3 percent increase, on average, in the vote share for nonmajor party candidates (conditional on the dependent variable being uncensored). The last model examines only those cases where a non-major 


\section{Table 1. Non-Major Party Voting by U.S. House District: Florida, 1992-2008}

\begin{tabular}{|c|c|c|c|c|c|}
\hline Variables & $\begin{array}{l}\text { Exp. } \\
\text { Sign }\end{array}$ & $\begin{array}{l}\text { GLS } \\
\text { Model } \\
\text { Coefficient } \\
\text { (robust s.e.) }\end{array}$ & $\begin{array}{l}\text { GLS } \\
\text { Model } \\
\text { Coefficient } \\
\text { (robust s.e.) }\end{array}$ & $\begin{array}{l}\text { Tobit } \\
\text { Model } \\
\mathrm{dF} / \mathrm{dx}^{\mathrm{a}} \\
\text { (s.e.) }\end{array}$ & $\begin{array}{l}\text { Tobit } \\
\text { Model } \\
\mathrm{dF} / \mathrm{dx}^{\mathrm{a}} \\
\text { (s.e.) }\end{array}$ \\
\hline Ballot Access Reform & + & $\begin{array}{l}1.17^{\mathrm{t}} \\
(.79)\end{array}$ & $\begin{array}{l}.20 \\
(.73)\end{array}$ & $\begin{array}{l}1.28 * * \\
(.53)\end{array}$ & $\begin{array}{l}-1.05 \\
(1.64)\end{array}$ \\
\hline$\%$ African American & - & $\begin{array}{l}-.04 * \\
(.03)\end{array}$ & $\begin{array}{l}-.05 * \\
(.03)\end{array}$ & $\begin{array}{l}-.01 \\
(.01)\end{array}$ & $\begin{array}{l}-.07^{\mathrm{t}} \\
(.05)\end{array}$ \\
\hline Med. District Income & - & $\begin{array}{l}-5.74^{\mathrm{E}-5} \\
\left(6.41^{\mathrm{E}-5}\right)\end{array}$ & $\begin{array}{l}-6.43^{\mathrm{E}-5} \\
\left(6.36^{\mathrm{E}-5}\right)\end{array}$ & $\begin{array}{l}-1.43^{\mathrm{E}-5} \\
\left(4.39^{\mathrm{E}-5}\right)\end{array}$ & $\begin{array}{l}-1.35^{\mathrm{E}-4} \\
\left(1.41^{\mathrm{E}-4}\right)\end{array}$ \\
\hline $\begin{array}{l}\text { \% Non-Major Party } \\
\text { Registered }\end{array}$ & + & $\begin{array}{c}.03 \\
(.07)\end{array}$ & $\begin{array}{l}.11^{\mathrm{t}} \\
(.08)\end{array}$ & $\begin{array}{l}-.06 \\
(.06)\end{array}$ & $\begin{array}{l}.35^{*} \\
(.20)\end{array}$ \\
\hline $\begin{array}{l}\text { 3rd Party Presidential } \\
\text { Candidate on Ballot }\end{array}$ & + & $\begin{array}{l}1.49 * \\
(.66)\end{array}$ & $\begin{array}{l}.98^{\mathrm{t}} \\
(.61)\end{array}$ & $\begin{array}{l}1.00 * * \\
(.34)\end{array}$ & $\begin{array}{c}1.33 \\
(1.15)\end{array}$ \\
\hline Major Party Missing & + & $\begin{array}{l}2.37 * * \\
(.96)\end{array}$ & $\begin{array}{l}2.38^{* *} \\
(.92)\end{array}$ & $\begin{array}{l}.88^{* *} \\
(.36)\end{array}$ & $\begin{array}{l}5.04 * * \\
(1.84)\end{array}$ \\
\hline Non-Major Party Missing & - & & $\begin{array}{l}-2.95 * * * \\
(.63)\end{array}$ & & \\
\hline Constant & & $\begin{array}{c}2.52 \\
(2.74)\end{array}$ & $\begin{array}{r}3.05^{\mathrm{t}} \\
(2.71)\end{array}$ & $\begin{array}{c}-.67 \\
(1.73)\end{array}$ & $\begin{array}{c}2.43 \\
(5.93)\end{array}$ \\
\hline $\begin{array}{l}\mathrm{Chi}^{2} \\
\mathrm{n}\end{array}$ & & $\begin{array}{l}9.46^{\mathrm{t}} \\
215\end{array}$ & $\begin{array}{l}26.76^{* * *} \\
215\end{array}$ & $\begin{array}{c}19.69 * * \\
215\end{array}$ & $\begin{array}{l}9.69^{t} \\
102\end{array}$ \\
\hline \multicolumn{6}{|c|}{$\begin{array}{l}{ }^{* * *} \mathrm{p}<.001 ; * * \mathrm{p}<.01 ; * \mathrm{p}<.05 ; \mathrm{t} p<.10 \text { (one-tailed tests) } \\
\text { a The marginal effects of the independent variables on the dependent variable on the condition the } \\
\text { data are uncensored }(y>0) .\end{array}$} \\
\hline
\end{tabular}

party candidate was on the ballot. To reiterate, removing the hurdle of ballot access might allow minor party and independent candidates to conserve more resources for the actual election. But, the finding in the fourth column does not support this proposition. The ballot reform variable does not meet the criterion for statistical significance, and actually returns a negative coefficient. $^{10}$

Considering the other variables in the models, only "Major Party Missing" is statistically significant across all four models. Arguably, the best 
chance for minor party candidates, given current election rules, is to try and fill the competition vacuum created by the absence of a major party. Districts with larger African American populations are associated with less nonmajor party voting in three of the four models, which suggests the importance of controlling for race in non-major party voting models. Medium district income returns negative coefficients across all models, as expected, but none reach standard levels of statistical significance. The percentage of non-major party registered voters in a district receives only secondary empirical support. This variable is not significant in the first and third models, and only marginally significant in the second. The mixed results suggest that people unwilling to align themselves with either of the two major parties are not necessarily loyal to non-major party candidates in a general election. ${ }^{11}$ Last, there does appear to be something akin to third party presidential coattails - three of the four models return statistically significant coefficients, suggesting that when third party presidential candidates are on the ballot, third party House candidates perform slightly better $(1.5 \%$ increase-Column 1 results).

\section{Discussion}

The Democratic and Republican Parties in Florida supported legal barriers to the inclusion of minor parties in electoral competition for seventy years (1928-1998). Once the ballot access barrier was removed, the threat of a non-major party candidate winning a Florida House seat became, in theory, more realistic. That is, a charismatic minor party candidate could conceivably captivate the electorate of a Florida House district and win a seat in the national legislature. Yet, this did not happen. No minor party candidates have won U.S. House seats in Florida (nor any state legislative seats) since the reform took place. Moreover, these findings suggest, at best, non-major party candidates have increased their vote share by about 1.3 percent. The research provides further evidence that the single-member district plurality rule hurdle is simply too difficult for minor parties to transcend. Ultimately, it appears that Duverger's Law (and possibly other barriers the law invokes such as a lack of media attention and fewer resources) and not ballot access is what moderates or prevents non-major party electoral success.

As a way to illustrate this finding, we can turn briefly to another state that did not follow the single-member district plurality rule electoral prescription for a period of time. It is difficult to test the true effects of this base electoral format on third party fortunes in the U.S. because there is so little variation in the use of the arrangement. However, from 1872 to $1980,{ }^{12}$ the state of Illinois elected members to the state House of Representatives in three member districts by way of cumulative voting (Adams 1996). The 
rules allowed voters three votes to distribute among up to three candidates (usually out of four). This voting method was designed with the explicit aim of enhancing minor party representation. Table 2 compares the proportion of state legislative seats held by representatives of minor parties in Illinois during the period of multi-member districts and the subsequent period of single-member districts. During the earlier period, the state averaged about 1.5 percent minor party representation in the state legislature. Since the adoption of single-member districts there has been no non-major party representation. $^{13}$

Table 2. Non-Major Party Representation: Illinois State House, 1872-2006

\begin{tabular}{lccc}
\hline & $\begin{array}{c}\text { Total \# } \\
\text { Legislative } \\
\text { Seats }\end{array}$ & $\begin{array}{c}\text { Total Seats Held } \\
\text { by Non-Major } \\
\text { Parties }\end{array}$ & $\begin{array}{c}\text { \% Non-Major } \\
\text { Party } \\
\text { Representation }\end{array}$ \\
\hline $\begin{array}{l}\text { Multi-Member Districts } \\
(1872-1980)\end{array}$ & 8727 & 138 & 1.58 \\
$\begin{array}{l}\text { Single-Member Districts } \\
(1982-2006)\end{array}$ & 1534 & 0 & 0.00 \\
\begin{tabular}{l} 
Source: Michael Durbin (2007). \\
\hline
\end{tabular}
\end{tabular}

In sum, the Australian ballot reform allowed major party state legislators to pass laws restricting non-major party ballot access (Evans 1917; Rusk 1970). It has been widely held that this allowance, in part, is responsible for the overall lack of non-major party representation in American legislatures. The evidence from Florida is that this may not be so. Although there is some additional electoral support for non-major party candidates associated with the removal of ballot access restrictions, there is nothing close to the level of support needed to prompt actual electoral victory. Moreover, the increase in levels of contestation and voting appear to be more a product of the novelty of equal ballot access than a sustained grassroots effort to establish new viable political parties.

\section{NOTES}

${ }^{1}$ Specifically, the Amendment (titled Revision 11) held that ballot access for nonmajor party candidates can be no more difficult than it is for the party with the largest number of registered voters in a given district or constituency (Florida Constitution 
Article VI). Prior to Revision 11, the two major parties could obtain ballot access in any of Florida's counties by collecting signatures from three percent of the party's registered voters or by paying a fee. In contrast, non-major party candidates were made to collect signatures from three percent of all registered voters in the relevant constituency and had no option of paying a fee (O'Neil 1998). Once passed, the wording of the Amendment allowed for two possible legislative interpretations. That is, the legislature could respond to Revision 11 by making ballot access for the two major parties more difficult, changing nothing for non-major parties, or make minor party ballot access easier (Perez 1998). They opted for the latter.

${ }^{2}$ Allegedly, legislators in the state were embarrassed that two-percent of voters had supported the Communist Party candidate for president (Boehlert 2000).

${ }^{3}$ The vote was 28-0 with nine Committee members absent (Winger 1998a).

${ }^{4}$ The measure also provided that candidates for the governor's office may run in primary elections without identifying a selection for lieutenant governor; corrected the voting age in Florida to 18 to coincide with the U.S. Constitution; provided for public financing of political campaigns if the candidates who avail themselves of the benefit agree to set spending limits; made school board elections non-partisan; and allowed all voters to cast votes in primary elections regardless of party affiliation if the winner of that contest will run unopposed in the general election.

${ }^{5}$ From 1992-2000, Florida had 23 congressional districts for a total of 115 observations, and from 2002-2008 Florida has had 25 districts for a total of 100 observations.

${ }^{6} \mathrm{We}$ include all non-major party voting in the dependent variable because it is nonmajor party voting that is the phenomenon of primary theoretical interest. Spoiled ballots, however, are not included in either the numerator or the denominator when calculating the percentage of votes cast. These are ballots that were cast, but not counted, due to a number of reasons including voting for more than one candidate for the same office or marking the ballot in such a manner that voter intent cannot be clearly determined.

${ }^{7}$ Data are obtained from U.S. Census Bureau. For the 1992-2000 election cycles, the 1990 Census figures are employed, and for the 2002-2008 cycles, the 2000 Census data are used.

${ }^{8}$ Census data are again employed to calculate median district income. However, the Consumer Price Index is used to convert Census values to constant 1999 dollars.

${ }^{9}$ One other interesting observation from Figure 2 is the mean vote for the 1992 election, which was atypical for the time period. It may be that the sensational presidential bid of the independent candidate, Ross Perot, increased voters' enthusiasm for choices beyond the major parties (Alvarez and Nagler 1995; Gold 1995). If so, this suggests another potential determinant of non-major party electoral success.

${ }^{10}$ It must be noted that Tobit coefficients represent the effect of $x$ on latent $y$ (or $y *$ ) and not the observed $y$ (see Roncek 1992). In our case, we are most interested in the expected value of $y$ conditional on $y$ being greater than zero. In order to obtain this value one must calculate the marginal effects of $x$ on $y$ if, $y>0$. This can be done using the "dtobit" command in Stata 9. It is the conditional effects of $x$ on $y$ that are reported in columns 3 and 4 of Table 1.

${ }^{11} \mathrm{~A}$ similar result was obtained when researchers tried to tie political independence to support for third party candidates in the American states (Norrander 1989; Burden and Greene 2000).

${ }^{12}$ For the 1964 election the entire State of Illinois was a single House District (Dubin 2007). This was a temporary response to the Supreme Court ruling that established the one person one vote principle (Adams 1996). 
${ }^{13}$ It can, also, be noted that minor parties have held about $1.5 \%$ of the state legislative seats in Massachusetts between 1857 and 2006; a state that allows for some multimember districts (Dubin 2007).

\section{REFERENCES}

Adams, Greg D. 1996. Legislative Effects of Single-Member vs. Multi-Member Districts. American Journal of Political Science 40(February):129-144.

Alvarez, R. Michael, and Jonathan Nagler. 1995. Economics, Issues and the Perot Candidacy: Voter Choice in the 1992 Presidential Election. American Journal of Political Science 39(3):714-744.

Ansolabehere, Stephen, and Alan Gerber. 1996. The Effects of Filing Fees and Petition Requirements on U.S. House Elections. Legislative Studies Quarterly 21(May): 249-264.

APSA (American Political Science Association) Committee on Political Parties. 1950. Toward a More Responsible Two-Party System. American Political Science Review 44 (Supplement).

Beck, Nathaniel, and Jonathan N. Katz. 1995. What to do (and not to do) with TimeSeries Cross-Section data. American Political Science Review 89(September):634647.

Boehlert, Eric. 2000. Al's Ballot Blues. November 16. http://archive.salon.com/politics/ feature/2000/11/16/ballots/print.html (November 12, 2007).

Bowler, Shaun, and David J. Lanoue. 1992. Strategic and Protest Voting for Minor Parties: the Case of the Canadian NDP. Political Research Quarterly 45(2):485-499.

Burden, Barry C. 2007. Ballot Regulations and Multiparty Politics in the States. PS 40(4):669-673.

Burden, Barry C., and Steven Greene. 2000. Party Attachments and State Election Laws. Political Research Quarterly 53(March):63-76.

Cobble, Steve, and Sarah Siskind. 2003. Fusion: Multiple Party Nominations in the United States. Washington, DC: Center for a New Democracy.

Dubin, Michael J. 2007. Party Affiliations in the State Legislatures: A Year by Year Summary, 1796-2006. Jefferson, NC: McFarland and Company.

Duverger, Maurice. 1954. Political Parties, Their Organization and Activity in the Modern State. New York: Wiley.

Dwyre, Diana, and Robin Kolodny. 1997. Barriers to Minor Party Success and Prospects for Change. In Multiparty Politics in American, eds. Paul S. Herrnson and John C. Green. Lanham, MD: Rowman and Littlefield Publishers, Inc.

Evans, Eldon C. 1917. A History of the Australian Ballot System in the United States. Chicago: University of Chicago Press.

Florida Constitution Article VI. Sections 1, 2, 5, 7. 1968. Revised by Revision No. 11, 1998.

Florida Department of State. Division of Elections. 1998. Election Results. 3 November 1998. http://election.dos.state.fl.us/elections/resultsarchive/Index.asp?Election Date $=11 / 3 / 1998 \& D A T A M O D E=($ November 1,2007$)$.

Gold, Howard J. 1995. Minor Party Voting in Presidential Elections: A Study of Perot, Anderson, and Wallace. Political Research Quarterly 48(December):751-773. 
Herrnson, Paul S. 1997. Two-Party Dominance and Minor Party Forays in American Politics. In Multiparty Politics in American, eds. Paul S. Herrnson and John C. Green. Lanham, MD: Rowman and Littlefield Publishers, Inc.

Hershey, Marjorie Randon. 2007. Party Politics in America, 12th ed. New York: Longman.

Hicks, John D. 1933. The Minor Party Tradition in American Politics. The Mississippi Valley Historical Review 20(1):3-28.

Hirano, Shigeo, and James M. Snyder, Jr. 2007. The Decline of Minor-Party Voting in the United States. Journal of Politics 69(1):1-16.

Lewis-Beck, Michael S., and Peverill Squire. 1995. The Politics of Institutional Choice: Presidential Ballot Access for Minor Parties in the United States. British Journal of Political Science 25(3):419-427.

Long, J. Scott. 1997. Regression Models for Categorical and Limited Dependent Variables. Thousand Oaks, CA: Sage Publications.

Lowi, Theodore J. 1983. Toward a More Responsible Three-Party System: The Mythology of the Two Party System and the Prospects for Reform. PS 16(4):699-706.

Lowi, Theodore J. 1999. Toward a Responsible Three-Party System: Plan or Obituary? In The State of the Parties, ed. John C. Green and Daniel M. Shea. Lanham, MD: Rowman and Littlefield, Inc.

Marquez, Myriam. 1998. Want to live in a True Democracy? Vote for Open Elections. Orlando Sentinel, September 14.

Mazmanian, Daniel A. 1978. Moving Outside or Around the Two-Party System: Minor Parties in Presidential Elections. In Parties and Elections in an Anti-Party Age, ed. Jeff Fishel. Bloomington: Indiana University Press.

Norrander, Barbara. 1989. Explaining Cross-State Variation in Independent Identification. American Journal of Political Science 33(2):516-536.

O’Neil, Deborah. 1998. Minor Parties Push for Equal Access to Ballot. St. Petersburg Times, August, 3.

Perez, Robert. 1998. Polling Sites Could Get Crowded. Orlando Sentinel, November 12.

Peterson, Geoff, and J. Mark Wrighton. 1998. Expressions of Distrust: Minor-Party Voting and Cynicism in Government. Political Behavior 20(1):17-34.

Polsby, Nelson W., and Aaron Wildavsky. 1996. Presidential Elections: Strategies and Structures in American Politics, 9th ed. Chatham, NJ: Chatham House.

Ranney, Austin, and Willmoore Kendall. 1956. Democracy and the American Party System. New York: Harcourt and Brace.

Riker, William H. 1976. The Number of Political Parties: A Reexamination of Duverger's Law. Comparative Politics 9(October):93-106.

Riker, William H. 1982. The Two-Party System and Duverger's Law. American Political Science Review 76(December):753-766.

Robeck, Bruce W., and James A. Dyer. 1982. Ballot Access Requirements in Congressional Elections. American Politics Research 10(1):31-45.

Roneck, Dennis W. 1992. Learning More from Tobit Coefficients: Extending a Comparative Analysis of Political Protest. American Sociological Review 57(4):503-507.

Rosenkranz, E. Joshua. 1996. Voter Choice '96: A 50 State Report Card on the Presidential Elections. New York: Brennan Center for Justice at New York University School of Law.

Rosenstone, Steven J., Roy L. Behr, and Edward H. Lazarus. 1996. Minor Parties in America, 2nd ed. Princeton, NJ: Princeton University Press.

Rusk, Jerrold G. 1970. The Effect of the Australian Ballot Reform on Split Ticket Voting, 1876-1908. American Political Science Review 76(4):1220-1216. 
Schattschneider, E. E. 1960. The Semi-Sovereign People: a Realist's View of Democracy in America. Hinsdale, IL: The Dryden Press.

Schmidt, David D. 1989. Citizen Lawmakers, the Ballot Initiative Revolution. Philadelphia: Temple University Press.

Sifry, Micah L. 2002. Spoiling for a Fight: Minor-Party Politics in America. New York: Routledge.

Sommerville, Richard, and Christina Clemenson. 1998. Improving Ballot Access in Florida. Green Party of Florida Fall 1998. http://www.greens.org/s-r/17/17-05.html (November 22, 2007).

Stratmann, Thomas. 2005. Ballot Access Restrictions and Candidate Entry in Elections. European Journal of Political Economy 21(March):59-71.

Tamas, Bernard, and Matthew Hindman. 2007. Do State Election Laws Really Hurt Third Parties? Ballot Access, Fusion and Elections to the U.S. House of Representatives. Paper presented at the Midwest Political Science Association. Chicago, IL.

Winger, Richard. 1997. Institutional Obstacles to a Multiparty System. In Multiparty Politics in American, eds. Paul S. Herrnson and John C. Green. Lanham, MD: Rowman and Littlefield Publishers, Inc.

Winger, Richard. 1998a. Florida Commission Backs Abolishing Petitions. Ballot Access News 13(10).

Winger, Richard. 1998b. Florida Voters Wipe Out Mandatory Petitions. Ballot Access News 14(8).

Winger, Richard. 1999. Ballot Access: a Formidable Barrier to Fair Participation. Available at: www.ballot-access.org/winger/fbfp.html (June 10, 2008). 